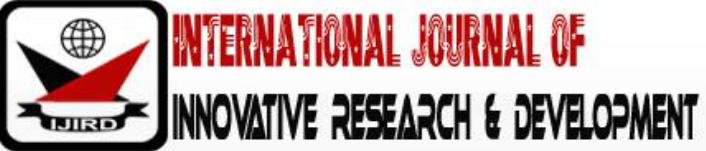

ISSN 2278 - 0211 (Online)

\section{Effect of Environmental Factor on the Seed Yield and Oil Content of Sunflower (Helianthus Annuus L)}

Oluwatoyosi Adaramodu
Student, Department of Institute of Botany,
Chinese Academy of Science, Beijing, China
Bolarin Joshua Adedeji
Lecturer, Department of Chemical Sciences,
Mollege of Natural and Applied Sciences, Salem University Lokoja, Kogi State, Nigeria
Modinat Adekoya
Lecturer, Department of Plant Science and Biotechnology,
Federal University, Oye-Ekiti State, Nigeria

\begin{abstract}
:
A field experiment was conducted on a Farm in Ekiti South-West Nigeria (Lat.7'37'23 N and log 5'13'15E with 1440 ft. above sea level) to evaluate the performance of two Sunflower genotypic varieties (SAMSUN 1 and SAMSUN 2) as affected by the geographical location and abiotic factors. Soil analysis result showed pH of 5. During the vegetative stage, $61 \mathrm{~cm}$ was recorded as the highest plant height for SAMSUN 1 and $46 \mathrm{~cm}$ was recorded as the highest plant height for SAMSUN 2. The number of leaves of SAMSUN 1 was 28 and 24 for SAMSUN 2 after 84days of planting. $1.8 \mathrm{~cm}$ was recorded as the final stem diameter for SAMSUN 1 and $1.6 \mathrm{~cm}$ for SAMSUN 2. Harvesting of seeds was carried after 124days of planting; the seed yield for SAMSUN 1 was $3.74 \mathrm{~kg}$ and $2.96 \mathrm{~kg}$ for SAMSUN 2. Proximate analysis on the seeds showed that SAMSUN 1 contained 5.88\% moisture,1.58\% ash, 7.10\% crude protein, 3.35\% fat and 3.35\% crude fiber while SAMSUN 2 contain $4.37 \%$ moisture, $2.05 \%$ ash, $6.45 \%$ crude protein, $4.16 \%$ fat and $4.16 \%$ crude fiber. Oil extraction was carried out on the seeds of the Sunflower using a Soxlet apparatus and $n$ - hexane as the extraction solvent. $400 \mathrm{ml}$ and $460 \mathrm{ml}$ of sunflower oil were recorded for the two varieties respectively. The oil composition analysis showed that SAMSUN 1 contained 5.37\% moisture, 0.74\% ash and 11.91\% crude protein and SAMSUM 2 contained 7.12\% moisture, $0.72 \%$ ash and $13.93 \%$ crude protein. The result of the experiment was compared with that from the northern region of Nigeria where it is predominately cultivated. It can be concluded after the whole experiment that sunflower will give more yield and oil in the northern region of Nigeria.
\end{abstract}

Keywords: Sunflower, abiotic factor, ph, proximate analysis, protein, fat, crude fiber

\section{Introduction}

Sunflower is an annual plant of the family Asteraceae with America as its origin (Hamed et al., 2012). Sunflower (Helianthus annuus L.) occupies the fourth position among vegetable oilseeds after soybean, oil palm and canola in the world (Rodriguez et al., 2002; Ahmad et al., 2011). Per 100 g, the seed enclose protein up to 20.78 g, total lipid (fat) up to $51.46 \mathrm{~g}$, ash up to $3.02 \mathrm{~g}$, and fiber up to $8.6 \mathrm{~g}$ with total energy of $2445 \mathrm{~kJ}$. The oil accounts for $80 \%$ of the value of the Sunflower crop, as contrasted with Soybean which derives most of its value from the meal (Hamed et al., 2012). The major goal of growing Sunflower is for its seed (achene) that contains oil (36-52\%) and protein (28-32\%) as reported by Rosa et al., (2009). There are two types of Sunflower seeds produced: oilseed and confectionary. Sunflower seeds can be sun dried or roasted and used as a medicine in South America.Mainly, there are three types of Sunflower oil available, namely MidOleic, Linoleic and High Oleic Sunflower oil. They all have different oleic levels, making the uses for Sunflower oil vast. (Schild et al., 1991) The crop has been receiving steady attention by various scientists from diverse disciplines in recent past because Sunflower oil is a premium oil and is widely used in the diets of patients with cardiovascular diseases as it contains very low cholesterol and high (90\%) unsaturated fatty acid concentration (Flagella et al., 2002; Qahar et al., 2010). Lately, there has been a steady increase in its demand globally because of the health risks posed by conventional method of production (Yiridoe et al., 2005). Compared to other edible oils, Sunflower oil has not been in wild circulation except in foreign countries. Sunflower is under-utilized in Nigeria because fewer farmers cultivate it, some farmers doubt that Sunflower will grow and the seeds are not even available (presently in Nigeria Sunflower seeds can only be gotten from Institute for Agricultural Research A.B.U Zaria) and only cultivated in the northern region of Nigeria (Showemimo et al., 2010). The above established importance of Sunflower justifies and rekindles the interest of National Institute with the genetic mandate of Sunflower improvement, Institute for Agricultural Research (IAR) of Ahmadu Bello University (ABU), 
Zaria to intensify Sunflower improvement, adaptation, registration and release to Nigerian farmers so as to compliment the short fall in vegetable oil production (Showemimo et al., 2010) this study was carried out to ascertain the effects of the environment on the growth of Helianthus annuus (Sunflower) and to determine the suitability of the two Sunflower genotypes for breeding work.

\section{Materials and Methods}

\subsection{Experimental Site}

The experiment was carried out on a farm in Ado-Ekiti, Ekiti State, a rainforest region of Nigeria with coordinate Lat 7'37'23 $\mathrm{N}$ and $\log$ 5'13'15E with $144 \mathrm{~m}$ above sea level.

\subsection{Seeds and Seed Origin}

The seeds used for the experiment were SAMSUN 1 and SAMSUN 2. SAMSUN 1 which was a Sunflower variety with an old name of Vniimk 8883 (SSL 803) and it originated from Romania while SAMSUN 2 was a Sunflower variety which originated from Canada, it was formally called Cherneanka 66 (SSL 806). The seeds were gotten from the Institute for Agricultural Research (IAR), Ahmadu Bello University (A.B.U), Zaria Nigeria with coordinate Lat. 11'5'7.9476" N and Log7'43'11.8020" E and elevation of 2,103 ft. above sea level.

\subsection{Type of Soil} composition

The soil used for the experiment was a Sandy Loam soil. Soil analysis test was done to elucidate the soil

\subsection{Replication and Harvesting}

Three (3) replications of 50 stands each were planted for each Sunflower variety. The seed were planted at the depth of $2 \mathrm{~cm}$ with inter and intra-row spacing of $70 \mathrm{~cm}$ by $30 \mathrm{~cm}$. The seeds were harvested 124 days after planting. Harvesting was done manually. Manual harvesting is practiced by cutting the umbel containing the seeds of the plant with a knife. The cleaning process followed immediately after harvesting. This involves hand picking of stones and dirt accumulated during the harvesting process.

\subsection{Data Collection and Analysis}

Data were collected every two weeks on the plant height, stem diameter and the number of leaves.The agronomic data from the two plant varieties were analyzed mathematically USING IBM SPSS 21 (Paired Samples Test)

\subsection{Oil Extraction and Determination of Vitamins}

Oil was extracted from the grounded samples of the seed using extraction solvent (n-haxane) in a Soxhlet apparatus. After the extraction process, SAMSUN 1 gave $400 \mathrm{ml}$ of oil and SAMSUN 2 gave $460 \mathrm{ml}$ of oil.

\subsubsection{Determination of Vitamin A}

A weighed sample of the oil containing not more than $1 \mathrm{~g}$ fat and at least 240 units of vitamin A was mixed with $30 \mathrm{ml}$ absolute ethanol and $3 \mathrm{ml}$ of $5 \%$ potassium hydroxide. The mixture was boiled gently under reflux for 30 minutes in a steam of oxygen free nitrogen. It was allowed to cool down and $30 \mathrm{ml}$ of water was added after which it was transferred to a separator. It was then washed with three (3) times $50 \mathrm{ml}$ ether and the vitamin A was extracted by shaking it for 1 minute, after complete separation, the lower layer was discarded and the extract was washed with $50 \mathrm{ml}$ water. The extract was washed and evaporated to $5 \mathrm{ml}$ and the remaining ether was removed in a steam of nitrogen at room temperature. The residue was dissolved in sufficient isopropyl alcohol to give a solution. The extinction was measured at 300, 310, 325 and $334 \mathrm{~nm}$ and the wavelength of maximum absorption (Pearson, 1975).

\subsubsection{Determination of Vitamin E}

$1 \mathrm{~g}$ of the sample was weighed into a $100 \mathrm{ml}$ flask fitted with a reflux condenser, to which $10 \mathrm{ml}$ of absolute ethanol was added with $20 \mathrm{ml}$ of $1 \mathrm{M}$ alcoholic Sulphuric acid. It was then refluxed for 45 minutes and allowed to cool down. $50 \mathrm{ml}$ of water was added and then transferred to a separating funnel of low actinic glass with additional $50 \mathrm{ml}$ of water. The unsaponifiable matter present was extracted with five (5) times $30 \mathrm{ml}$ diethyl ether, and the extract was evaporated at low temperature. While protecting from sunlight, the residue was dissolved in $10 \mathrm{ml}$ absolute alcohol, then the standard and the sample were transferred to a $20 \mathrm{ml}$ volumetric flask and $5 \mathrm{ml}$ of absolute alcohol was added followed by $1 \mathrm{ml}$ concentrated Nitric acid. The flask was placed in water bath at $900^{\circ} \mathrm{C}$ for 3 minutes. The flask was cooled under running water and the volume was made up to $20 \mathrm{ml}$ with absolute alcohol. The absorbance was measure at $470 \mathrm{~nm}$. (Pearson,1975)

\subsubsection{Determination of Vitamin C}

The vitamin C content was determined using the ascorbic acid as the reference compound. $200 \mu \mathrm{l}$ of the extract was pipetted and mixed with $300 \mu \mathrm{l}$ of 13.3\% Trichloroacetic acid (TCA) and 75 $\mu \mathrm{l}$ 2,4-dinitrophenylhydrazine (DNPH). The mixture was incubated at $370{ }^{\circ} \mathrm{C}$ for $3 \mathrm{hrs}$ and $500 \mu \mathrm{l} 65 \% \mathrm{H}_{2} \mathrm{SO}_{4}$ was added and the absorbance was read at $520 \mathrm{~nm}$. (Benderitter et al., 1998). 


\subsubsection{Determination of Vitamin $\mathrm{K}$}

The procedure for color development as adopted from Menotti's procedure. The solution in which the concentration of vitamin $\mathrm{K}$ was being determined was placed in a flask and sodium pentacyanoamineferroate reagent was added. The solution was stirred and then allowed to stand for fifteen minutes to allow maximum color development. When the blue color has developed, the absorption of the solution was measured by means of a spectrophotometer at $650 \mathrm{~nm}$

\subsection{Proximate Analysis}

\subsubsection{Moisture}

The moisture content of the sample was determined using air oven (AOAC, 2000). The petri dishes were washed and dried in air oven. The dishes were then transferred into the desiccator which allowed cooling. The weights of the petri dishes were measured. $3 \mathrm{~g}$ of sample was weighed into a dry petri dish and the contents were transferred into an oven maintaining a temperature of $105^{\circ} \mathrm{C}$. The content was allowed to dry at this temperature for $6 \mathrm{hrs}$. The petri dish with its content was removed from the oven and placed in the desiccator. After cooling, the weight was measured, after drying to constant weight. The percentage moisture was calculated using the following equation: Initial sample weight (g) - dry sample weight $(\mathrm{g})$ x $100=$ Moisture $\%$

Total weight

\subsubsection{Ash}

Clean crucibles were ignited at $350^{\circ} \mathrm{C}$ for about $15 \mathrm{mins}$, cooled in a desiccator and weighed. $1 \mathrm{~g}$ of each sample was transferred into each of the appropriately labelled crucibles and then reweighed. Then, the crucibles with their contents were transferred into the muffle furnace at $5500^{\circ} \mathrm{C}$ for about 5hours. After complete ashing, the crucibles were allowed to cool in a desiccator and then reweighed. The percentage of ash was then calculated using the formula,

$$
\text { Ash content }(\%)=\frac{\text { Weight of crucible with ash }(\mathrm{g})-\text { Weight of empty crucible }(\mathrm{g}) \times 100}{\text { Weight of sample }(\mathrm{g})}
$$

\subsubsection{Crude Protein}

Crude protein of the samples was estimated using Kjeldahl procedure. A sample of $0.5 \mathrm{~g}$ and a blank was estimated in the digestion tube. For digestion at high temperature, $10 \mathrm{ml}$ of concentrated $\mathrm{H}_{2} \mathrm{SO}_{4}$ and $1.1 \mathrm{~g}$ digestion mixture were added in the tube. The digestion tubes were then set in digestion chamber fixed at $420^{\circ} \mathrm{C}$ for 45 minutes ensuring water supply, easier gas outlets etc. After digestion the tubes were allowed to cool and $5 \mathrm{ml}$ of Sodium thiosulphate $\left(\mathrm{Na}_{2} \mathrm{~S}_{2} \mathrm{O}_{3}, 33 \%\right)$ and $30 \mathrm{ml}$ Sodium hydroxide $(\mathrm{NaOH})$ solution were added in each tube. Then the distilled extraction was collected with $25 \mathrm{ml}$ of Boric acid $(4 \%)$ and titrated with standard $\mathrm{HCl}(0.2 \mathrm{~N})$. The Nitrogen values obtained was converted into percentage of crude protein by multiplying with a factor of 6.25 assuming that protein contains $16 \%$ nitrogen.

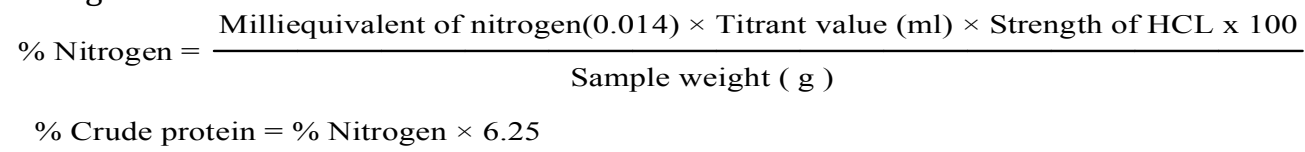

\subsubsection{Crude Lipid}

Crude lipid was determined by extracting a weighed quantity (3g) of samples with analytical grade acetone in ground joint Soxhlet apparatus. Extraction was allowed to continue by heating in the electric heater at the temperature $70^{\circ} \mathrm{C}$ until clear acetone (without oil) was seen in siphon, which took about 3 hours. Then the round bottom flask of the apparatus was separated and the extract was transferred to a pre-weighed beaker and left for evaporation of acetone. After the evaporation of acetone, only the lipid was left in the beaker and the crude lipid was calculated in percentage thus,

$\%$ Crude lipid $=$

Weight of beaker with lipid - Weight of empty beaker x 100

Weight of sample (g)

\subsubsection{Crude Fiber}

A small amount of finely grinded sample (2g) was taken into a filter crucible and was inserted into the hot extraction unit (Hot Extractor, Model-1017). Pre-heated 0.128M of $\mathrm{H}_{2} \mathrm{SO}_{4}$ was added into the reagent heating system and few drops of alcohol $\left(\mathrm{C}_{8} \mathrm{H}_{18} \mathrm{O}\right)$ were added through the valves. The mixture was digested for 30 minutes. Acid was then removed from it by filtering and washing with boiling water. The residue in the flask was boiled with $0.223 \mathrm{M}$ of potassium hydroxide $(\mathrm{KOH})$ for 30 minutes and then filtered with subsequent washing in boiling water and acetone. The residual content was then dried in an oven at $105^{\circ} \mathrm{C}$ for a few hours and then ignited in muffle furnace at $550^{\circ} \mathrm{C}$ for 3 hours. The loss of weight represented the crude fiber. Then percent crude fiber was calculated by the following formula,

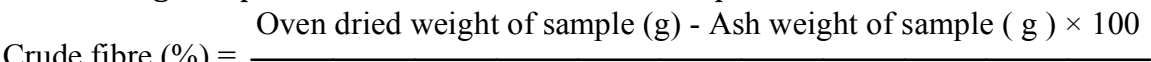

Weight of sample (g) 


\subsubsection{Minerals}

The minerals were analyzed from the solution obtained by the first seed dry ashing. $1 \mathrm{~g}$ of each sample was placed in a crucible and placed in a muffle furnace at $550^{\circ} \mathrm{C}$ for 5 hours to ash and then transferred into desiccators to cool. The cooled ash was dissolved in $10 \% \mathrm{HCl}$, filtered into a clean graduated sample bottles and the solution was made up to $50 \mathrm{ml}$ with distilled water. The solution was aspirated into the atomic absorption spectrophotometer to obtain the mineral concentration.

\section{Result and Discussion}

\subsection{Seed Description}

After harvesting, the seeds of the Sunflower were measured in kilogram using a measuring scale. Weight per 100 seeds of SAMSUN 1 (803) was $6 \mathrm{~g}$ while Weight per 100 seeds of SAMSUN 2 (803) was 6g. The total weight of harvested SAMSUN 1 and SAMSUN 2 seeds was $3.74 \mathrm{~kg}$ and $2.96 \mathrm{~kg}$ respectively.

\subsection{Agronomic Performance}

An overall agronomic performance that was observed on the two different Sunflower varieties SAMSUN 1 and SAMSUN 2 between December 2017 and April 2018 presented in table 1 below and figure 1 to 6 shows that there was a significant variation between the two varieties of sunflower. At the end of the experiment, the overall results show that the height of SAMSUN 1 and SAMSUN 2 were statistically significant as the probability level of 0.001 was lower than the critical value of 0.05 . Likewise the number of leaves on both plants was significantly different with p-value of 0.004 lower that the critical value of 0.05 . The same conclusion goes for the size of the stem as the p-value of 0.044 was less than the critical value of 0.05 .

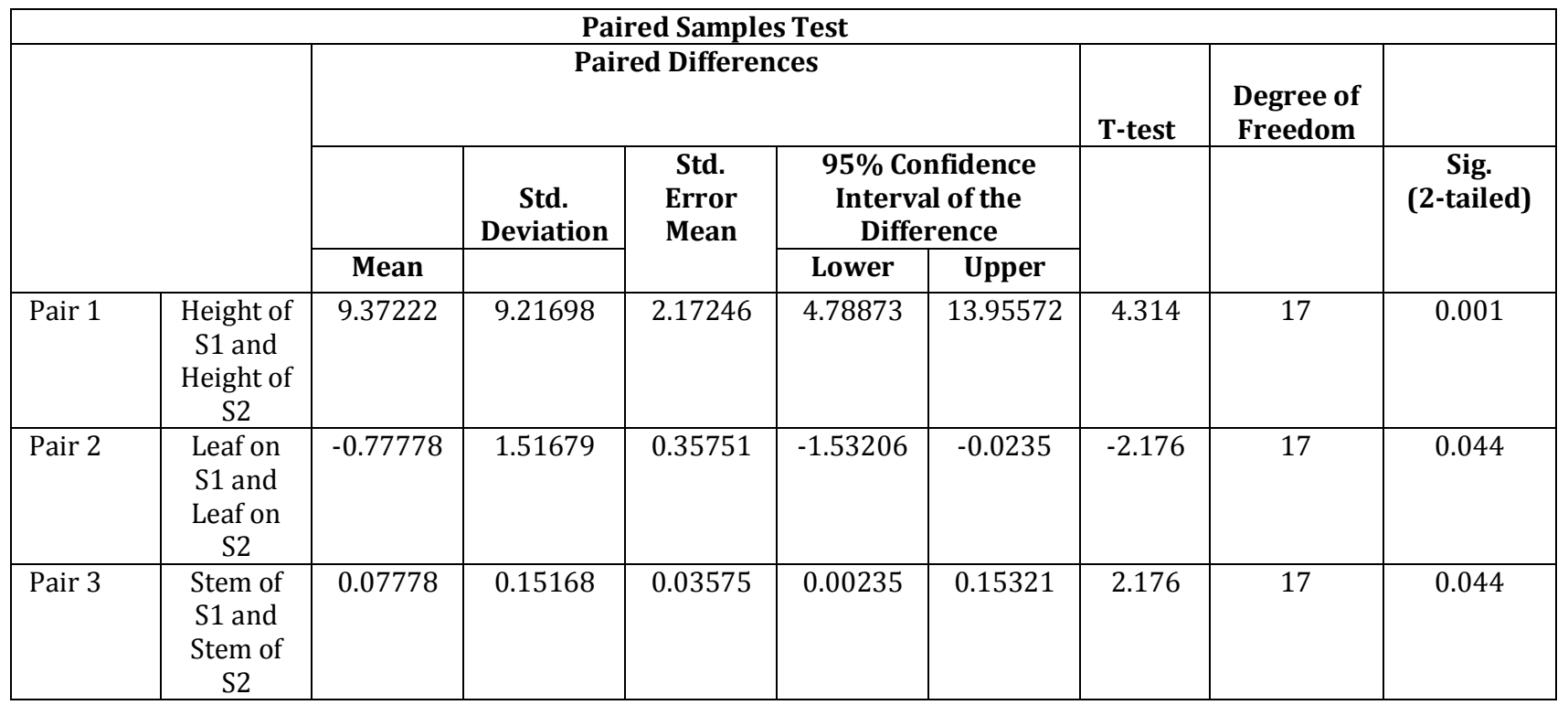

Table 1: Paired Samples Test

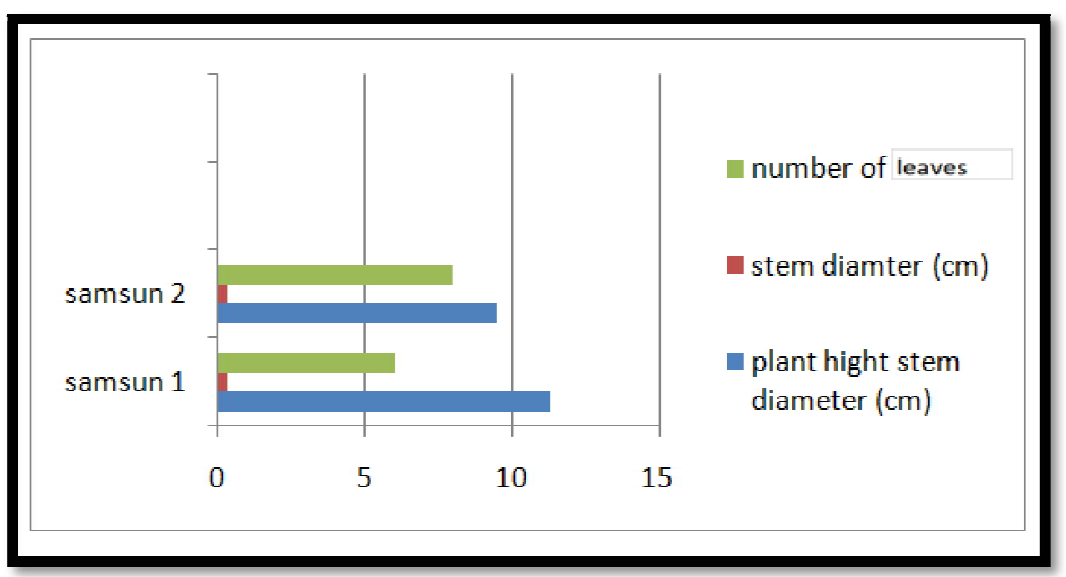

Figure 1: 14 Days after Planting 


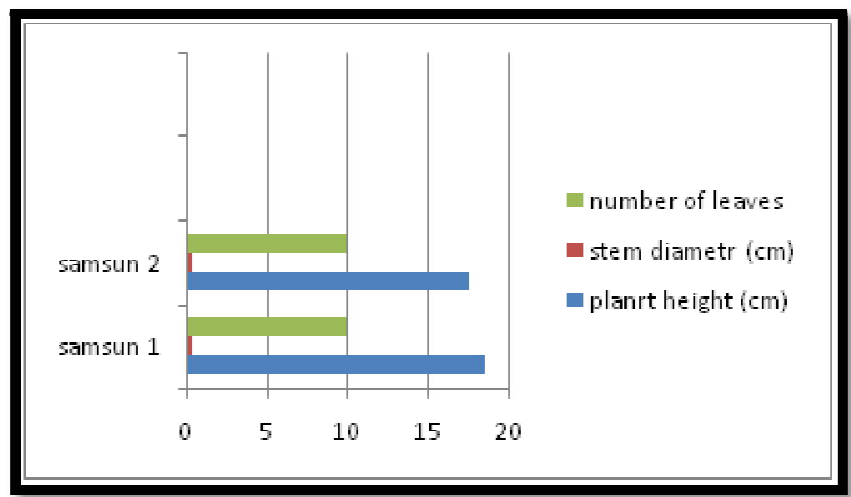

Figure 2: 14 Days after Planting

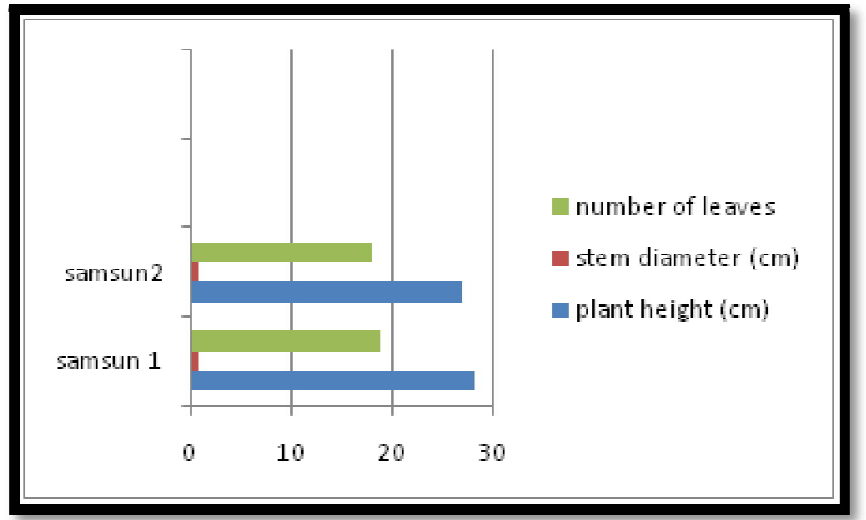

Figure 3: 42 Days after Planting

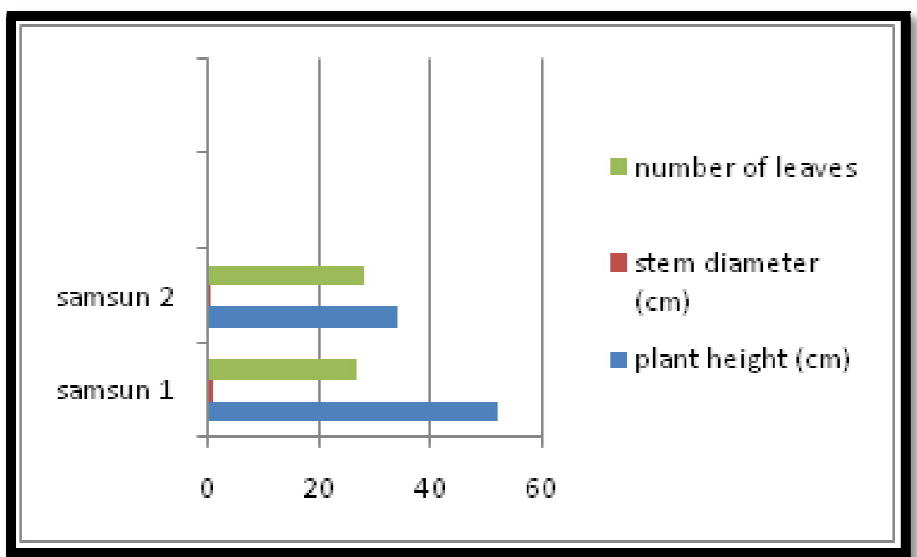

Figure 4: 56 days after planting

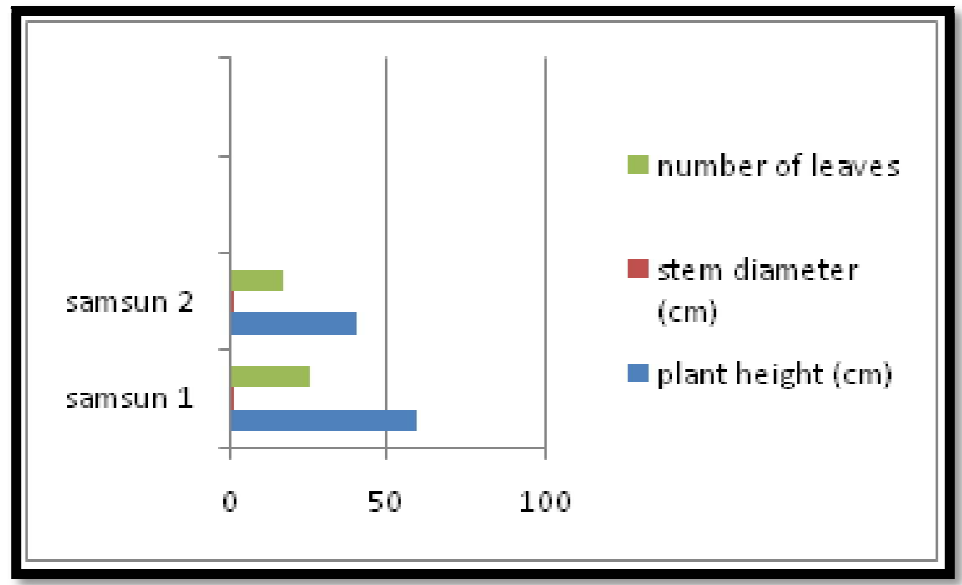

Figure 5: 70 Days after Planting 
$\operatorname{sansun} 2$

$\operatorname{san} \operatorname{sun} 1$

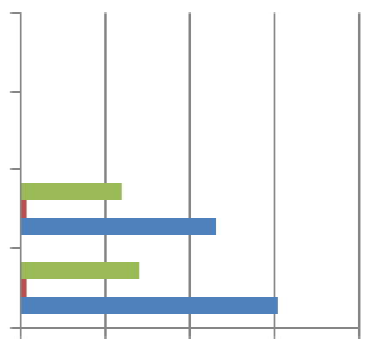

number of leaves

- stem diameter

plant height

Figure 6: 84 Days after Planting

SAMSUN 1 performed better during the vegetative stage when compared to SAMSUN 2 as shown in figure 7 below but when compared with the data from similar research conducted in Zaria, it was observed that environmental difference played a significant role. The average plant height recorded by Showemimo etal.,

(2010) showed that when planted in Zaria, the plant height was $120 \mathrm{~cm}$ and $125 \mathrm{~cm}$ respectively. However, when compared with the Sunflower planted in Ekiti State, the average height recorded was $61 \mathrm{~cm}$ and $46 \mathrm{~cm}$ respectively.

\section{Plant Height of SAMSUN 1 and 2}

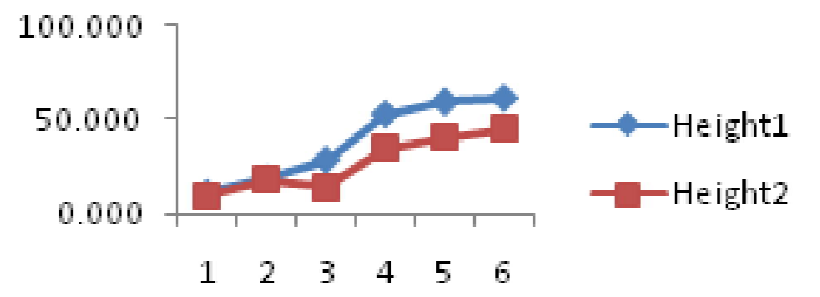

Figure 7: A Plot Showing Variation in Plant

Height of SAMSUN 1 And 2

A steady increase in the number of leaves on both plants which began to decrease between the tenth and twelfth week of growth was observed as shown in figure 8 below. The average number of leaves recorded according to Showemimo et al., (2010) was 20 and 24 for SAMSUN 1 and 2 while that of Ekiti State was 28 and 24 for SAMSUN 1 and 2.

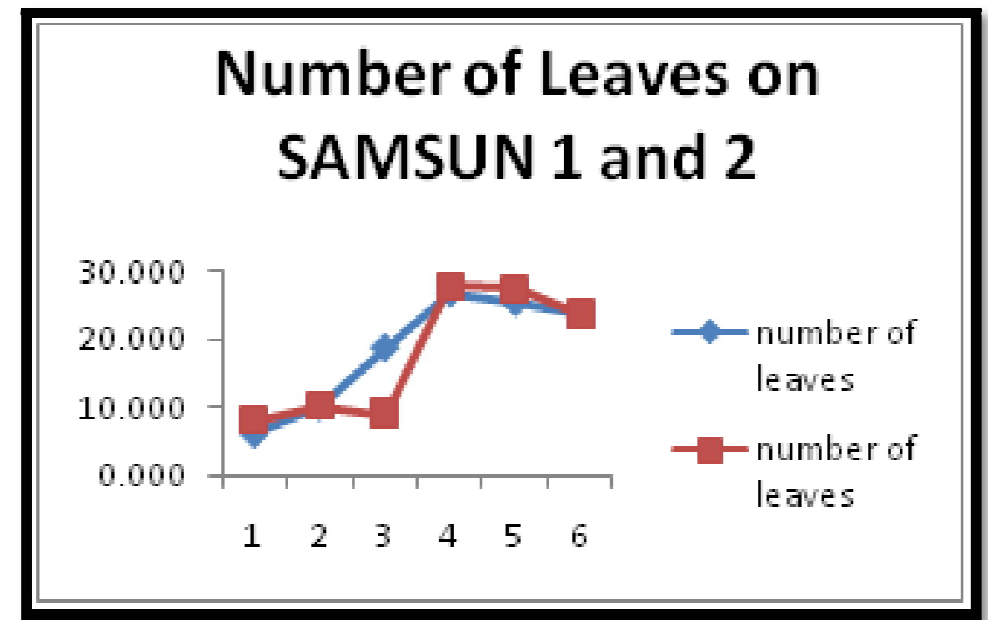

Figure 8: A Plot Showing Variation in the Number of Leaves Produced by SAMSUN 1 and 2 over a Period of Time

A steady growth was also observed in the stem diameter of both SAMSUN 1 and 2. 


\section{Stem diameter of SAMSUN}

\section{1 and 2}

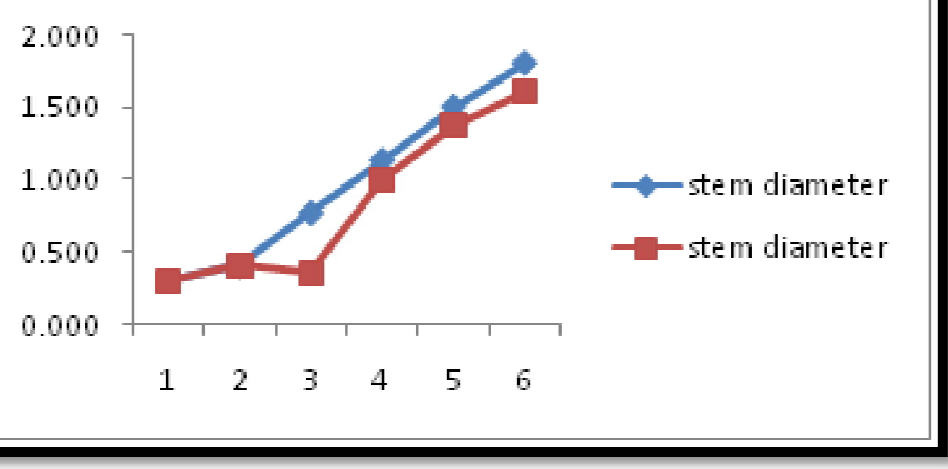

Figure 9: A Plot Showing Slight Variation in Stem Diameters of SAMSUN 1 and 2 over a Period of Time

\subsection{Vitamins}

The vitamin contents of the extracted oils from SAMSUN 1 and 2 were analyzed and the result presented in table 2 below.

\begin{tabular}{|c|c|c|c|c|c|c|c|c|}
\hline & \multicolumn{2}{|c|}{ VIT.A mg/g } & \multicolumn{2}{c|}{ VIT. E mg/g } & \multicolumn{2}{c|}{ VIT. C mg/g } & \multicolumn{2}{c|}{ VIT. K mg/g } \\
\hline SAMSUN 1 & 1488.03 & 1484.99 & 2.736184 & 2.757264 & 1.632515 & 1.745102 & 0.042106 & 0.041915 \\
\hline SAMSUN 2 & 1809.74 & 1811.35 & 3.882936 & 3.904016 & 4.784958 & 4.559784 & 0.057967 & 0.058413 \\
\hline
\end{tabular}

Table 2: Vitamin Contents of Sunflower Seed

The oil richly contains vitamin E, which prevents dangerous free radicals from oxidizing the body cholesterol; this is in line with Flagella et al., 2002 and Qahar et al., 2010. It also contains vitamins A, D, C which keeps the skin supple and functions as excellent face moisturizer with its antioxidant activity. This oil helps in the regeneration of skin cells and in the prevention of various body aches, (Flagella et al., 2002; Qahar et al., 2010).

\subsection{Proximate Composition}

The shafts of the two varieties SAMSUN 1 and 2 contain $7.10 \%$ and $6.45 \%$ crude protein respectively with $3.35 \%$ and $4.16 \%$ crude fat respectively, thus they can be used as animal feeds in line with the report from BIO, (2005).Due to difference in the geographical areas, the Sunflower seeds had a high moisture content of 5.88\% and $4.29 \%$ for SAMSUN 1 and 2 respectively(Table 3) while that of Zaria was reported to contain $2.01 \%$ and $1.68 \%$ respectively; this is suggestive of higher rainfall in the rainforest zone of Nigeria. A decrease was also observed in the ash content and the crude fiber level of the sunflower planted in the southwest region of Nigeria in comparison with the high ash and fiber content of the sunflower planted in the northern part of Nigeria. In the nutritional composition of the oil, the crude protein recorded by Showemimo et al., (2010) was $17.2 \%$ and $19.72 \%$ for SAMSUN 1 and 2 respectively but the ecological and environmental factor in the rainforest region of Nigeria played a role by reducing the protein content of the two oils giving $11.91 \%$ and $13.92 \%$ respectively as shown in table 3 below.

\begin{tabular}{|c|c|c|c|}
\hline Sample & $\begin{array}{c}\text { Moisture } \\
\text { content }\end{array}$ & Ash content & $\begin{array}{c}\text { Crude } \\
\text { protein }\end{array}$ \\
\hline SAMSUN 1 & $5.88 \%$ & $0.74 \%$ & $11.91 \%$ \\
\hline SAMSUN 2 & $4.29 \%$ & $0.73 \%$ & $13.92 \%$ \\
\hline
\end{tabular}

Table 3: Oil Composition

\subsection{Mineral Composition}

The mineral component of the seeds of SAMSUN 1 and 2 was analyzed and the result showed that SAMSUN 1 contains (in ppm) $13.600 \mathrm{Na}, 42.200 \mathrm{~K}, 3.693 \mathrm{Mg}, 0.625 \mathrm{Fe}$, and $1.310 \mathrm{Zn}$ while SAMSUN 2 contains $15.100 \mathrm{Na}, 37.800 \mathrm{~K}$, $1.965 \mathrm{Mg}, 0.371 \mathrm{Fe}$ and $0.960 \mathrm{Zn}$.

\section{Conclusion}

This research study carried out has confirmed that Sunflower can be grown in Ekiti State, a rainforest zone of Nigeria. Since the plant is prone to lodging if planted during raining season, the best time to plant Sunflower is during the dry season to avoid yield lost. The proximate analysis result also revealed that the plant is rich and that it contains protein, fiber, moisture and ash. This study also showed that Sunflower has a low fat content and this is responsible for its reported uses in food preparation in different parts of the world. The presence of vitamin E which is a very powerful antioxidant also confirmed its use in preventing asthma. The plants take few months to get to maturity thus the attention 
of farmers most especially in the southwest region of the country should be brought to this plant as a source of food and revenue.

\section{References}

i. Ahmad, M., Iqbal, J., Kaleem, S., Wasaya, A., Ishaque, M. 2011. Qualitative analysis of spring planted Sunflower hybrids as influenced by varying nutritional area. Pakistan Journal of Nutrition 10:291-295.

ii. Benderitter, M., Maupoli, V., Vergely, C., Dalloz, F., Briot and Rochette, L.1998. Studies by electron paramagnetic resonance of the important of iron in hydroxyl scavenging properties of ascorbic acid in plasma: effect of iron chelator. Fundamental and clinical pharmacology 12: 510-643.

iii. Flagella, Z.T., Rotundo, E., Tarantino, R., Di Caterina, De Caro, A. 2002. Changes in seedyield and oil fatty acid composition of high oleic Sunflower (Helianthusannuus L.) hybrids in relation to the sowing date and water regime. Agronomy Journal 17: 221-230.

iv. Hamed, S.F., Suzanne, M., Wagdy, Megahed, M.G. 2012. Chemical characteristic and antioxidant capacity of Egyptian and Chinese Sunflower seed. Life science Journal 9:320 328

v. Person, D. 1975. Chemical Analysis of food, 7th ed. Churchill ligstone, London pp 419-620

vi. Qahar, A., Khan, Z.H., Anwar, S., Badshan, H., Ullah, H. 2010. Nitrogen use efficiency, yield and other characteristics of Sunflower (Helianthus annuus L.) hybrids as affected by different levels of nitrogen. Biological Diversity and Conservation 3:121-125.

vii. Rodrigues, D., Romero-Garcia, J., Rodriguez-Garcia, R., Angualo-Sanchez, J.L., 2002. Characterization of proteins from Sunflower leaves and seeds: relationship of biomass and seed yield. In trends in new crops and new uses. AAIC Fifth NationalSymposium, Purdue Univ., West Lafayette, in, pp. 143-149.

viii. Rosa, P.M., Antoniassi, R., Freitas, S.C., Bizzo, H.R., Zanotto, D.L., Oliveria, M.F., Castiglioni, V.B.R. $2009 . \quad$ Chemical composition of Brazilian sunflower varieties. Helia 32:145-156.

ix. Schild J., D. Baltensperger, D. Lyon, G. Hein, C. Kerr, 1991. Sunflower production in Nebraska. S. Extension Bulletin 25. North Dakota University, Fargo, ND 76p.

X. Showemimo, F., Orakwue, F., Ado, S., Yeye, M., Tanimu, B., Mahmud,M., Misari, S., Akpa, A.,Egwuruba, E., Omega, J., Ndirika, V. 2010. Recommendation for registration and release of four Sunflower varieties.

xi. The Biology of Helianthus annuus L. BIO. 2005. Biology Document 2-3.

xii. Yiridoe, E.K., Bonti-Ankomah, S., Martin, R.C. (2005). Comparison of consumer perceptions and preference toward organic versus conventionally produced foods: A review andupdate of the literature. Renewable Agriculture and Food Systems, 20:193-205 